\title{
NOTAS SÔBRE 0 MELHORAMENTO DA BATATA NOS ESTADOS UNIDOS (*)
}

\section{A. S. Costa}

\section{INTRODUÇÃO}

A batata (Solanum tuberosum L.) é um dos alimentos básicos do norte-americano. Ela é usada pràticamente em tôdas as refeições. O pirão de batatas, a batata frita ou assada são as formas mais comuns em que é servida. O seu uso na mesa do norte-americano corresponde mais ou menos ao papel do arroz na mesa brasileira.

A produção de batatas nos Estados Unidos é enorme. No quadro I reproduzimos dados referentes à produção americana nos últimos 21 anos.

\section{QUADRO I}

PRODUÇAO DE BATATA NOS ESTADOS UNIDOS DURANTE O PERÍODO 1922/1942 (17,3) (**)

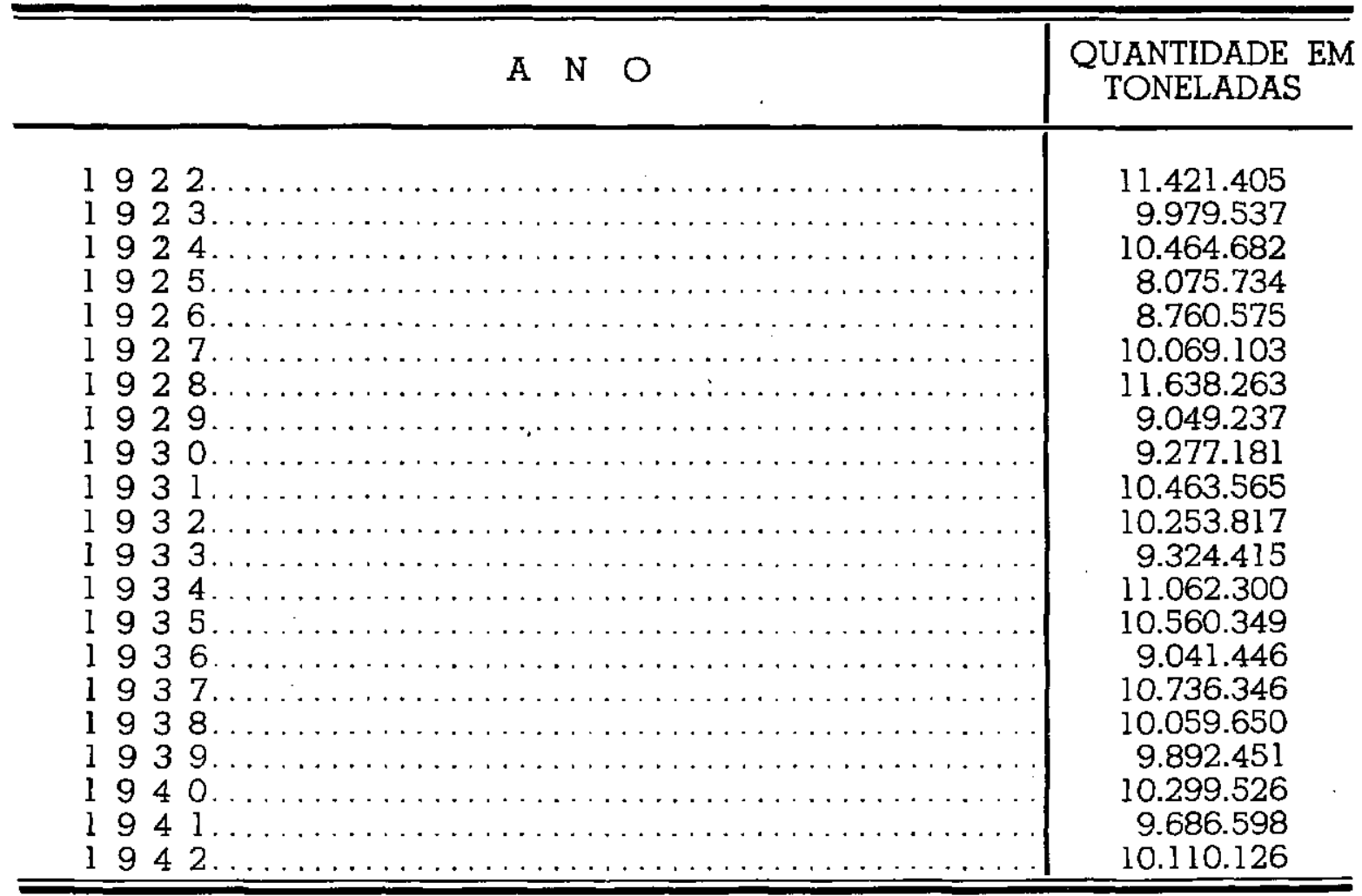

(*) Parte do relatório de viagem apresentado pelo autor ao Govêrno do Estado. Viagem feita sob os auspícios da Fundação Rockefeller, N. York.

(**) Os números entre parênteses referem-se à literatura citada. 
O consumo de batata, per capita, nos Estados Unidos, é bastante elevado. Stuart (26) calcula que durante o período 1915-1919, o consumo médio, per capita, foi ligeiramente acima de 63,5 quilogramas. Usando-se um cálculo semelhante ao feito por aquêle autor, verifica-se que o consumo médio, per capita, para os últimos 10 anos, foi de 54,3 quilogramas, aproximadamente.

Sendo um dos elementos básicos da alimentação americana, compreende-se a razão da enorme importância que é dada a esta cultura naquele país. Ao lado dos numerosos problemas de adubação, práticas culturais, etc., que são estudadas em numerosas estações experimentais, dá-se uma importância tôda especial ao melhoramento da cultura pela criação de novas variedades. A importância dêste último problema pode ser aquilatada pelo fato de que, em 1929, foi organizado o "National Potato Breeding Program" (21) destinado a coordenar os trabalhos de melhoramento da batata feitos nos diversos Estados do país. Atualmente, fazem parte dêste plano de trabalho cooperativo, experimentadores de cêrca de 30 Estados. À testa dêste projeto acha-se o dr. F. J. Stevenson, geneticista da "Division of Fruit and Vegetable Crops and Diseases", do Departamento Federal de Agricultura em Washington. A finalidade dêste programa é sistematizar o melhoramento da batata e promover um melhor intercâmbio de idéias e material entre os diversos cooperadores. Assim, os "seedlings" que são criados na Estação Experimental de Beltsville no Estado de Maryland, ou em qualquer outra das estações experimentais, são oportunamente distribuidos aos outros experimentadores. Anualmente, os resultados experimentais verificados pelos diversos cooperadores são resumidos em uma publicação mimeografada que é distribuida aos interessados.

Que a criação do "National Potato Breeding Program" foi de grande valor para a cultura da batata nos Estados Unidos, evidencia-se pela observação dos dados do quadro II, referentes à produção de semente certificada de 10 das novas variedades criadas pelos métodos genéticos e que foram distribuidas aos lavradores depois da organização dêste programa.

Os dados do quadro II mostram que cêrca de $28 \%$ das sementes certificadas produzidas nos Estados Unidos, em 1942, pertenceram às variedades criadas pelos geneticistas. Algumas das novas variedades ganham terreno, contìnuamente, sôbre as antigas variedades estandardes. É de se presumir que, dentro de alguns anos, a maioria da área cultivada com batatas nos Estados Unidos seja plantada com semente de novas variedades. Reconhece-se, não obstante, que algumas das variedades estândardes difìcilmente seriam sobrepujadas em produção e qualidade, se pudessem ser cultivadas isentas de moléstias e pragas (24). 


\section{QUADRO II}

PRODUÇĀO DE SEMENTE CERTIFICADA DE 10 DAS VARIEDADES RECENTEMENTE CRIADAS. DADOS PARA O ANO DE 1942

\begin{tabular}{|c|c|c|}
\hline VARIEDADE & $\begin{array}{c}\text { Quantidade de } \\
\text { semente certificada } \\
\text { produzida. (Quilo- } \\
\text { gramas) }\end{array}$ & $\begin{array}{c}\text { Percentagem em } \\
\text { relação do total } \\
\text { de sementes certifi- } \\
\text { cadas produzidas } \\
\text { no país }\end{array}$ \\
\hline 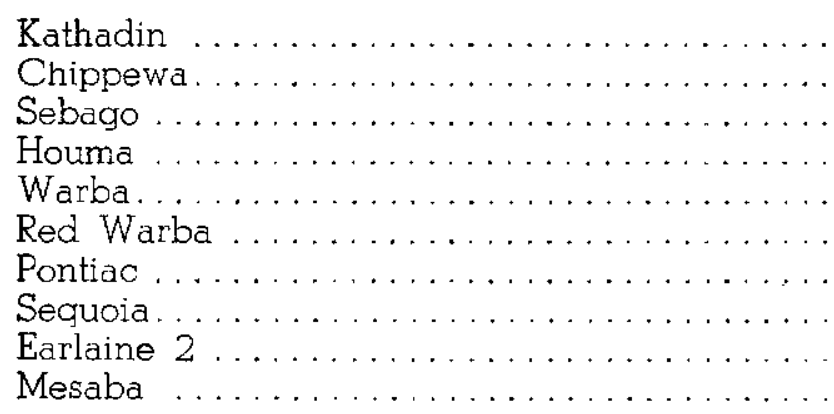 & $\begin{array}{r}80.605 .555 \\
35.246 .844 \\
27.028 .372 \\
7.492 .253 \\
1.432 .633 \\
1.422 .091 \\
1.136 .317 \\
1.035 .120 \\
1.020 .710 \\
241.401\end{array}$ & $\begin{array}{r}14,5 \\
6,3 \\
4,8 \\
1,3 \\
0,3 \\
0,3 \\
0,2 \\
0,2 \\
0,2 \\
0,04\end{array}$ \\
\hline
\end{tabular}

\section{A CRIAÇÃO DE NOVAS VARIEDADES DE BATATA}

$\mathrm{Na}$ criação de novas variedades, ao lado de caraterísticos comerciais satisfatórios, dá-se enorme valor às qualidades de resistência às moléstias e insetos, particularmente às moléstias de virus. Compreende-se fàcilmente o valor dado à resistência às moléstias de virus no projeto de criação de novas variedades, sabendo-se que elas são as responsáveis pela chamada degenerescência do tubérculo-semente. Mesmo sob condições favoráveis parā produção de tubérculos-sementes, é empreendimento difícil e caro a manutenção dêstes com baixo teor em virus. Algumas das novas variedades criadas mostram resistência a uma ou mais, das moléstias de maior importância, facilitando assim a conservação do estogue de tubérculos-sementes com baixa percentagem destas.

Muitas das moléstias ou pragas, contra as quais se está procurando variedades resistentes, podem ser controladas por outros métodos. Tal é o caso, por exemplo, do crestamento fitóftora. Êste pode ser controlado satisfatòriamente por pulverizações. $\bigcirc$ uso de uma variedade resistente é, porém, o método ideal para contrôle de uma moléstia ou praga.

A criação de novas variedades de batatas já é assunto velho nos Estados Unidos. Sòmente nos últimos cinqùenta anos do século passado, mais de uma centena de novas variedades foi originada naquele país 
(21). A maioria das variedades criadas nos Estados Unidos, no passado, foi obtida por via sexual. Apenas 6,7\% destas foram originadas por mutações somáticas (5).

Os primeiros experimentadores que se ocuparam em criar novas variedades dispunham de material relativamente escasso e de poucos conhecimentos relativos à genética da planta. A-pesar disso, foram obtidas variedades muito valiosas; algumas das variedades estândardes plantadas atualmente nos Estados Unidos foram originadas por estes pioneiros do melhoramento desta planta.

Hoje em dia, dispõe-se de material bastante abundante e variado, que pode ser utilizado no melhoramento da batata. Stevenson e Clark (21) dão uma lista das espécies selvagens e cultivadas de batata. Muitas destas possuem caraterísticos valiosos, tais como resistência ao frio, a insetos, moléstias, etc. Não obstante a existência dêste farto material, a maioria dos projetos de melhoramento desta planta nos Estados Unidos ainda é feita com material de Solanum tuberosum. O professor Reddick, da Universidade de Cornell, é um dos poucos que trabalham com outras espécies. Êle tem usado $S$. demissum como um dos pais, em cruzamentos com variedades cultivadas, a-fim-de obter imunidade ao crestamento fitóftora. Das variedades já distribuidas aos lavradores, nenhuma delas foi obtida a partir de cruzamentos com outras espécies do grupo. É claro que a criação de variedades por cruzamentos inter-específicos é um processo mais demorado e que oferece maiores dificuldades. Podendo-se encontrar os caraterísticos desejados dentro de Solanum tuberosum não há vantagem alguma em procurá-los em outras espécies. Contudo, em face da multiplicidade dos problemas que surgiram no melhoramento desta Solanaceae, certos caracteres, que não são encontrados dentro da espécie $\mathcal{S}$. tuberosum, terão que ser procurados nesse repositório valioso que é o grupo de espécies cultivadas e selvagens, aparentadas com a batata.

Ao lado de um material genético mais farto, dispõem os geneticistas de hoje de grande número de informações sôbre o problema. Grande número de variedades têm sido estudadas no que se refere aos caraterísticos de valor que possue, se são férteis, etc., etc. A evidência obtida demonstrando que Solanum tuberosum possue o tipo de herança tetrasômica (10) veio também elucidar certos problemas e facilitar os trabalhos genéticos com esta planta. 
Como já dissemos, a maioria das novas variedades obtidas nos Estados Unidos tem sido proveniente de cruzamentos feitos entre variedades cultivadas. Conhecendo-se bem os caraterísticos das variedades usadas nos cruzamentos, tem sido possível obter combinações de bastante valor. A esterilidade do pólen de muitas variedades dificulta um tanto os trabalhos de cruzamentos, porém têm sido usadas pelo lado materno muitas das variedades que possuem caraterísticos de valor, mas cujo pólen não é viável. Também tem sido estudado o papel do ambiente na frutificação e verificou-se que a adição de luz artificial às plantas de certas variedades promovia melhor formação de frutos (6, 7, 27).

Stevenson e Clark (21) descrevem em detalhe a técnica de cruzamento para batatas.

\section{RESISTÊNCIA ÀS MOLÉSTIAS}

Os "seedlings" uma vez criados e submetidos a testes preliminares com relação aos caraterísticos dos tubérculos, produção, hábito vegetativo, etc., são posteriormente ensaiado squanto à resistência às moléstias $e$ insetos. O teste para resistência às moléstias é efetuado de diferentes maneiras, em geral, para uma moléstia de cada vez. Consiste preliminarmente em se expor um certo número de plantas de cada clone à infeção pela moléstia em questão, de modo que sejam grandes as probabilidades de infeção.

Para o caso das moléstias de virus, usou-se, a princípio, inocular as plantas por enxertia de tubérculos ("tuber-grafting") ou de plantas, com material afetado. Verificou-se, porém, que os testes assim efetuados eram muito severos e que o comportamento de uma variedade sob condições de infeção natural era diferente do observado em experiências de inoculação por enxertia. Na natureza, a maioria das moléstias de virus da batata dissemina-se por afídeos. Verificou-se que variedades suscetíveis a um determinado virus por enxertia, podiam ser imunes ao mesmo virus sob condiçǒes naturais. Isto mostra que a variedade é potencialmente suscetível, mas que o vetor da moléstia na natureza não é capaz de transmitir o virus para plantas dessa variedade. Como, em última análise, o que interessa é o comportamento sob condições naturais, pode-se considerar tais variedades como imunes, no sentido prático da palavra. Para êsses casos criou-se a expressão: Imune quanto à infeção por afídeos. As variedades Earlaine, Kathadin e S. 24642, por 
exemplo, são imunes ao virus A (Marmor solani H.), quanto à infeção por afídeos, mas são suscetíveis à infeção por enxertia (16).

Os testes por enxertia ainda são usados para verificação da imunidade absoluta, ao passo que a resistência sob condições naturais é estudada nos chamados testes de exposição em campo.

\section{O TESTE DE EXPOSIÇÃO ÀS MOLÉSTIAS DE VIRUS}

Os testes de exposição às moléstias de virus podem ser divididos em duas fases: 1) a exposição dos clones à infeção pela moléstia pròpriamente dita $e$ 2) a determinação das plantas que foram infetadas, para julgamento de resistência relativa.

\section{A exposição à infeção}

Para o caso dos virus $\mathbf{A}, \mathbf{X}$ (Marmor dobium H.), Y (Marmor cucumeris $\mathrm{H}$. var. Upsilon $\mathrm{H}$.) e do virus do enrolamento da fôlha (Corium solani $\mathrm{H}$.), o teste de exposição é efetuado da mesma maneira. Dez a vinte plantas de cada clone são sumetidas à infeção em comparação com plantas de uma variedade suscetível, usada como contrôle. A fonte de inóculo ou foco de infeção é constituido por tubérculos de uma variedade suscetível, produzidos por planta afetada pelo virus em questão. O ensaio, em geral, é plantado de uma das maneiras ilustradas no gráfico seguinte:

$$
\begin{aligned}
& +=+\mathrm{O}+\mathrm{t}+++ \\
& +=+0+\quad 0=0=0 \\
& +=+0+\quad+t++ \\
& t=+0+\quad 0=0=0 \\
& +=+0+\quad++++ \\
& t=+0+\quad 0=0=0 \\
& +=+0+\quad++++ \\
& +=+0+\quad 0=0=0 \\
& +=+\mathrm{O}+\mathrm{t}+++ \\
& t=+0+\quad 0=0=0 \\
& + \text { foco } \\
& \text { = contrôle } \\
& \text { clone }
\end{aligned}
$$


A plantação de fileiras alternadas, dos clones, focos e contrôles não é tão eficiente como a alternância, nas fileiras, de plantas dos clones a serem ensaiados, com plantas focos e de plantas contrôle com plantas focos. Usando-se o método das plantas alternadas, pode-se diminuir o número das plantas ensaiadas a cinco por clone. Naturalmente, podem ser feitas pequenas modificações na disposição das plantas no campo, mas estes dois métodos são os mais usados. Quando a estação não é favorável para o desenvolvimento dos afídeos, pode-se iniciar a infestação das plantas focos com colônias de afídeos criados em laboratório. Um outro método que também tem sido empregado para auxiliar a disseminação, consiste em cortar fôlhas das plantas focos que tenham afídeos e colocar sôbre as plantas a serem ensaiadas (15).

\section{A determinação das plantas infetadas}

A diagnose das plantas infetadas nos campos de exposição não é feita pela observação dos sintomas na estação corrente. Colhem-se um ou dois tubérculos-amostras de cada uma das plantas dos clones ensaiados e dos contrôles, para serem plantados no ano seguinte. Êles podem ser plantados em estufas ou em campo. As plantas provenientes dos tubérculos-amostras é que são examinadas para diagnose daquelas que haviam contraído a moléstia no campo de exposição.

Enrolamento da fôlha - No caso dos clones estudados quanto à resistência ao enrolamento da fôlha, a diagnose é geralmente feita pela observação dos sintomas apresentados pelas plantas provenientes dos tubérculos-amostras. A comparação dos dados obtidos para os diferentes clones e respectivos contrôles, dá uma idéia da resistência relativa que possuem. Ainda não foi encontrada verdadeira resistência ao enrolamento da fôlha. Algumas variedades mostram, porém, uma tendência para escapar à moléstia e sabe-se que esta tendência é hereditária. Sob o ponto de vista prático, isto é resistência. Stevenson et al. (25) referem que as variedades estrangeiras Albion, Friso, West Brabander, Triumph, Bevelander, Moordeling, Império, Kepplestone Kidney e Shamrock, não contraem o enrolamento da fôlha tão ràpidamente como a variedade Green Mountain. Destas, Triumph foi a única que permaneceu isenta de enrolamento da fôlha em 5 anos de experiências. Entre as variedades americanas estudadas pelos mesmos autores, Kathadin e Houma parecem possuir alguma resistência. Progênies de cruzamentos feitos com Kathadin, Império e Kepplestone Kidney têm apresentado resistência. A resistência ao enrolamento da fôlha também tem 
que ser encarada quanto à resistência dos tubérculos à "net-necrosis" causada pelo mesmo virus. As variedades Kathadin, Chippewa, Houma e Sebago, mesmo quando afetadas pelo virus do enrolamento da fôlha, são resistentes à "net-necrosis".

Virus $\mathbf{X}$ - As variedades de batata podem reagir a êste virus de quatro maneiras diferentes: podem ser imunes, portadoras, podem mostrar mosaico das fôlhas ou exibir necrose (16). Quanto aos testes de exposição em campo, elas podem ser grupadas em: imunes, raramente infetadas e infetadas fàcilmente (16).

No estudo da resistência dos clones ao virus $\mathbf{X}$, a diagnose é feita por inoculação artificial em plantas indicadoras, sendo obtido o inóculo das plantas provenientes dos tubérculos-amostras colhidos nos campos de exposição. Datura stramonium e Capsicum sp. são as plantas usadás como indicadoras. A última espécie é mais sensitiva a $\mathbf{X}$ do que a primeira, dando reação mesmo quando inoculada com formas fracas de $\mathbf{X}$.

A maioria das variedades comerciais americanas são portadoras do virus X. A-pesar-de estarem 100\% infetadas, elas são capazes de produzir boas colheitas. É difícil de se dizer se haverá vantagem, sob o ponto de vista comercial, em obter variedades imunes a X. Imunidade a $\mathbf{X}$ já foi, porém, encontrada em diversos "seedlings". Assim, o "seedling" U.S.D.A. 41956, por exemplo, é imune ao virus X, mesmo por enxertia. Êste "seedling" não é usado comercialmente, mas tem prestado ótimos serviços em estudos sôbre virus da batata, servindo de planta-filtro para $\mathbf{X}$. São também imunes a $\mathbf{X}$ os "seedlings" 774-67 e 792-114 (23). Imunidade a $\mathbf{X}$ tem sido fàcilmente obtida em progênies de cruzamentos, dos quais um dêstes "seedlings" foi usado como pai.

Virus $\mathbf{Y}$ - Os tubérculos colhidos das plantas, que expostas ao virus $\mathbf{Y}$ contrairam a moléstia causada por êste virus, usualmente originam plantas que exibem sintomas. Estes podem ser de 3 tipos: 1) rugosidade fraca ; 2) palidez das nervuras e rugosidade; 3) necrose severa, palidez das nervuras e rugosidade (15). Há, porém, "seedlings" que podem ser considerados portadores dêste virus.

A diagnose do virus $\mathbf{Y}$ é feita por inoculação mecânica em plantas de fumo ou de Nicotiana sylvestris. Obtém-se o inóculo das plantas produzidas pelos tubérculos-amostras. Jones e Vincent (8) fazem a diagnose para $\circ$ virus $\mathbf{Y}$ inoculando plantas de fumo com $\circ$ suco de plantas a serem diagnosticadas e adicionando ao inóculo de tais plantas, um outro, contendo $\mathbf{X}$. Neste caso, as plantas de fumo inoculadas deverão apresentar os sintomas de "spot-necrosis" caso o inóculo das plantas a serem diagnosticadas contivesse $\mathbf{Y}$. 
Em testes feitos com enxertia de tubérculo, não foi encontrado nenhum "seedling" que não fôsse infetado pelo virus $\mathbf{Y}$ (15). Aparentemente, os estudos a respeito dêste virus não estão tão avançados como a respeito dos já mencionados.

Virus $\mathbf{A}$ - $O$ teste para o virus $\mathbf{A}$ não é feito por inoculação mecânica, pois êste virus não passa tão fàcilmente pelo suco como $\mathbf{X}$ e $\mathbf{Y}$. As plantas provenientes dos tubérculos-amostras, colhidos nos campos de exposição, podem apresentar um dos seguintes sintomas: 1) necrose ; 2) clorose e rugosidade; 3) mosaico. Quanto à resistência, as variedades ou clones podem ser grupados em imunes à infeção por afídeos, raramente infetados e fàcilmente infetados (16). Para uma diagnose mais precisa de $\mathbf{A}$ ou para verificar se alguma das plantas pode conter o virus em forma latente, usa-se inocular plantas da variedade Green Mountain por enxertia de aproximação $(15,16)$. Caso a planta a ser diagnosticada contenha A, então a planta dè Green Mountain sôbre a qual foi enxertada mostrará os sintomas do chamado mosaico fraco ("mild mosaic"). Uma outra maneira de dignosticar $\mathbf{A}$, consiste em enxertar as plantas a serem examinadas sôbre cavalos de Irish Cobbler. Obtém-se desta maneira a produção de tubérculos aéreos no cavaleiro, caso êste contenha $\mathbf{A}$ (11). Uma reação semelhante também é obtida quando se enxerta cavaleiro contendo $\mathbf{X}$ sôbre cavalo de plantas U.S.D.A. 41956 (11).

Imunidade ao virus $\mathbf{A}$ sob condições de campo já foi encontrada em Irish Cobbler, Kathadin, Earlaine, Chippewa e S. 24642. Progênies de cruzamentos entre plantas imunes ao virus $\mathbf{A}$, cruzadas com as plantas imunes a $\mathbf{X}$, podem muitas vêzes ser imunes a ambos (16). A variedade Sebago é resistente ao virus $\mathbf{A}$.

\section{Outras moléstias de virus}

Além dos virus mencionados, a resistência de clones e variedades a outras moléstias de virus de menor importância econômica ou de importância regional, também está sendo estudada. Em Wisconsin estuda-se a resistência das variedades ao "yellow dwarf", tendo sido verificado que a variedade Sebago apresenta resistência satisfatória. Está sendo também estudada a resistência ao virus causador de tubérculos afilados. Esta é uma moléstia mais importante em Nebraska, onde estão sendo feitos os principais estudos a êste respeito. Já foi encontrada resistência a êste virus, mas os estudos a êste respeito ainda estão na fase preliminar. 


\section{O TESTE DE EXPOSIÇÃO AO CRESTAMENTO FITÓFTORA}

Alguns investigadores preferem realizar os testes com relação à resistência ao crestamento fitóftora em estufas, onde as condições de temperatura e umidade possam ser reguladas. Outros alegam que as condições em que tais testes são efetuados, são muito artificiais e demasiadamente severas, preferindo realizá-los mais ou menos sob condições naturais.

Nos testes de campo, os clones a serem expostos à infeção são plantados em fileiras alternadas com uma variedade contrôle, conhecidamente suscetível. Em geral, escolhe-se para o ensaio uma localização favorável à disseminação da moléstia, como uma baixada perto de um rio, etc. Em ocasião oportuna, procede-se à inoculação artificial do ensaio. Como inóculo, poder-se-à usar uma suspensão de esporângios do fungo causador ou então proceder à germinação dêstes em laboratório e efetuar a inoculação com os zoosporos. É claro que, para que a inoculação dos ensaios seja eficaz, deve-se escolher época favorável para se proceder à mesma, como, por exemplo, nas tardes de dias chuvosos.

Os esporângios usados na preparação do inóculo para pulverização das plantas, podem ser obtidos de fôlhas de plantas afetadas ou de culturas do fungo, preparadas em laboratório sôbre fatias cruas de batata, Trabalhos recentes efetuados na Universidade de Maine, mostraram que é possível cultivar Phytophthora infestans com bastante sucesso, em meio nutritivo de agar, esterilizado, contanto que se adicionem certas leguminosas ao meio, depois de terem sido autoclavadas diversas vêzes com mudança de água.

A determinação da resistência é feita em um ou dois protocolos, dando-se um valor arbitrário variando de $\mathbf{0}$ a $\mathbf{5}$ para os diferentes graus de infeção: Zero para os clones não afetados e cinco para os que são gravemente afetados; graus 1, 2, 3 e 4, para os valores intermediários.

Um fato que pode complicar o problema de seleção de variedades resistentes ao crestamento fitóftora, é a possibilidade de um aumento em virulência, do organismo causador Phylophthora infestans. Foi verificado por Reddick e Mills $(13,14)$ que clones que haviam mostrado resistência ao fungo $P$. infestans quando o inóculo era obtido de variedades comerciais, podiam ser suscetíveis a um inóculo mais virulento. $\bigcirc$ aumento em virulência, pode ser obtido por passagem do fungo em varieda. des de resistência crescente até se obter uma cultura que será virulenta para plantas de clones que seriam imunes à estirpe comum do fungo. Êste aumento em virulência do fungo, ocorre também sob condições naturais (14). 
As varièdades President, Sebago, 336-123, 336-144, 336-202 e 336-302 (19), são resistentes ao crestamento fitóftora. Outras variedades que apresentam resistência são: Ekishirazu, Ackersegen e o "seedling" 45349 (22). Reddick e Mills (14) afirmam que Evergreen possue alguma resistência e que se encontra imunidade ao crestamento fitóftora em Solanum demissum e outras espécies do México. Uma das variedades comerciais que também apresenta certa resistência a esta moléstia (24), é a Sequoía.

\section{O TESTE DE EXPOSIÇÃO À SARNA COMUM}

Para determinação da resistência à sarna comum, escolhe-se um terreno já bastante infestado. A adição de cal na razão de 2.500 quilogramas por hectare é aconselhável (21). A plantação continuada de batata na mesma área servirá para aumentar a infestação. Em um tal terreno, procede-se à plantação dos clones em comparação com uma variedade contrôle, suscetível à moléstia. A plantação poderá ser feita em fileiras alternadas ou com as plantas dos clones e do contrôle, alternadas na fileira. Julga-se a resistência dos clones pela percentagem de tubérculos afetados e também pelo caráter das lesões apresentadas. Devido à existência de raças fisiológicas de Actinomyces scabies, torna-se duvidoso se os clones selecionados para um determinado lugar não terão resistência apenas para as raças locais do organismo causador. Leach et al. (9) verificaram em ensaios realizados em Minnesota, que podiam ser isoladas duas raças fisiológicas dêste organismo. Estas raças foram denominadas raças 1 e 2. Um "seedling" N. 0 5-10-1 era suscetível à raça $\mathrm{l}$ e muito resistente à raça 2 . A var. Jubel ( ?) era moderadamente suscetível à raça 1 e também muito resistente à raça 2. A-pesar da existência destas raças fisiológicas do organismo causador da sarna, fomos informados de que clones selecionados quanto à resistência à sarna comum, sob as condições de Aroostook Farm no Estado de Maine, tinham também mostrado resistência em localidades situadas em outros Estados.

Reddick (12) observou imunidade à sarna comum em Solanum commersonii, $\mathcal{S}$. chacoense, $S$. caldasii var. glabrescen, $S$. jamesii e numa variedade não identificada. Estas espécies foram cultivadas por dois anos seguidos em solo bastante infestado pelo organismo causador da sarna e sempre se mostraram imunes à moléstia. Resistência d̀ sarna comum, sob as condições dos Estados Unidos, foi encontrada por Stevenson e Clark (21) em diversas variedades européias já anteriormente conhecidas pela sua resistência a essa moléstia. Entre elas as variedades 
Hindenburg, Richters' Jubel, Ackersegen, Arnica e Hindenburg x Centifolia N. ${ }^{\circ}$, mostraram menos de $1 \%$ da quantidade de sarna observada nos tubérculos de Green Mountain, a variedade usada como contrôle. A variedade Ostragis, de origem européia, também mostrou resistência. Entre as variedades de origem americana, Russet Rural, Russet Burbank e Mahr Russet mostraram resistência intermediária. A variedade Golden apresentou apenas a quinta parte da sarna observada nos tubérculos de Green Mountain, em ensaios efetuados em 1935. O "seedling" 44537 mostrou-se muito resistente à sarna e, além disso, tem a vantagem de possuir pólen viável e ser auto-fértil.

O TESTE DE EXPOSIÇÃO A MURCHA BACTERIANA CAUSADA POR PHYTOMONAS SOLANACEARUM (E. F. S.) BERGEY ET AL.

Para estudo da resistência dos clones a esta moléstia, procede-se de maneira idêntica à relatada para a sarna comum. Os clones a serem ensaiados são plantados em comparação com variedades contrôles em um terreno bastante infestado. Podem ser plantados em fileiras alternadas, ou plantas alternadas na. fileira. O julgamento da resistência deverá ser feito pela observação da murcha das partes aéreas e também pelo exame dos tubérculos.

A variedade Kathadin é a que tem mostrado mais resistência a esta moléstia. A variedade Sebago também tem alguma resistência.

\section{O TESTE DE EXPOSIÇÃO À MOLÉSTIA "RING-ROT"}

O organismo causador da moléstia "ring-rot", Phytomonas sepedonica (Spieckermann) Magrou, não permanece no solo de um ano para outro, sob as condições dos Estados Unidos. Não se pode, por conseguinte, usar um terreno infestado para estudo da resistência dos clones a esta moléstia. A inoculação artificial dos tubérculos com cultura pura, não deu bons resultados em Maine, assim como inoculação das plantas por meio de infeções com suspensões de bactéria. O processo mais satisfatório para estudo da resistência dos clones e variedades a esta moléstia foi o de esfregar fatias de um tubérculo infetado sôbre a superfície cortada dos tubérculos a serem ensaiados (4), que são então plantados imediatamente. A determinação da resistência é feita pelo número de plantas que mostram a murcha, mas torna-se também necessário o exame dos tubérculos, pois variedades existem que são resistentes à murcha da parte aérea, mas exibem sintomas nos tubérculos.

As variedades Friso e President, ambas de origem européia, são resistentes a "ring-rot". Nos testes realizados, quatro seleções de um 
cruzamento President $\mathrm{x}$ Kathadin escaparam à infeção, o mesmo se dando com um clone proveniente do cruzamento 41956 x Earlaine. Um outro clone derivado do cruzamento Earlaine x 43055 mostrou sòmente $4 \%$ de ataque (4).

\section{RESISTENCIA AOS INSETOS}

A resistência aos insetos tem sido estudada principalmente em relação ao "hopper-burn" causado por Empoasca fabae Hains, ao "psyllidyellows" causado por Paratrioza cockerelli (Sulc.), aos danos causados por diversas espécies de afídeos e aos danos causados pela pulguinha (Epitrix sp.).

\section{Resistência ao "hopper-burn"}

Tem sido estudada principalmente em ensaios de campo. Nestes estudos, dois fatôres principais são tomados em consideração: a popu: lação do inseto nas plantas dos diferentes clones ou variedades e o grau de injúria apresentado pelas plantas. Aparentemente, não há uma correlação entre a população de ninfas encontrada em certos clones com a extensão do dano apresentado pelos mesmos (18).

$\mathrm{Na}$ determinação da população do inseto causador, Sleesman e Stevenson (18) usam tomar de 5 a 10 fôlhas escolhidas ao acaso, de plantas de cada clone ou variedade. $\mathrm{Na}$ amostra obtida procede-se à contagem das ninfas. Para se ter dados sôbre a injúria causada pelo inseto, classificam-se as plantas dos clones ou variedades de acôrdo com a área danificada da fôlha, podendo-se usar classes de 0 a 5. Zero significa ausência de injúria e cinco, de 80 a $100 \%$ da área da fôlha injuriada. Os valores intermediários variam de classe para classe, em $20 \%$. Allen et al (2) usam a seguinte técnica para determinar a população dêste inseto nas diferentes variedades ou clones: De 10 plantas escolhidas ao acaso, em cada repetição de uma variedade ou clone, colhe-se a sexta flor a contar de cima. Nestas, conta-se o número de ninfas. Para determinação do grau de injúria, Allen e Rieman (1) colhem a terceira e a sexta fôlhas de 10 plantas escolhidas ao' acaso em cada repetição da variedade ou clone. Estas amostras são então trazidas ao laboratório e de cada uma fôlha tomam-se três folíolos para exame: o folíolo apical e os dois laterais próximos a êste. Em seguida, separam-se os tecidos injuriados dos tecidos sadios por meio de uma tesoura, seca-se em separado $e$, finalmente, determina-se a percentagem de tecidos injuriados em relação aos sadios, na base de pêso sêco. 
Resistência ao ataque pelo inseto causador de "hopper-burn", foi encontrada em Solanum polyadenium. As espécies $S$. chacoense, $S$. commersonii e $S$. caldasii mostraram-se também muito resistentes (18).

Entre as variedades cultivadas, Sequoia, Kathadin, Rural New Yorker N. ${ }^{\circ} 2$ e diversos clones mostraram-se resistentes à injúria causada por êste inseto (18). Allen e Rieman referem que Houma e Kathadin mostram tolerância a "hopper-burn", sob as condições de Wisconsin (1.)

Foi verificado, em testes efetuados com relação à resistência ao crestamento fitóftora, que os clones selecionados para resistência a esta moléstia deveriam também possuir resistência a "hopper-burn". De outra maneira, uma vez usado o clone resistente em plantações comerciais e não sendo estas pulverizadas, as plantas seriam sèriamente prejudicadas pelo ataque dêste inseto, devido à ausência da pulverização, a qual comumente age como um repelente.

\section{Resistência aos afídeos}

Êste é um problema cujo estudo só foi iniciado mais recentemente'; é de enorme interêsse em relação às moléstias de virus e oferece uma outra possibilidade para o contrôle destas. Além disso, é sabido que os afídeos, mesmo sem levar em conta o seu papel como vetores de moléstias de virus, causam uma certa diminuição na produção.

teste para resistência aos afídeos, pode ser efetuado em campo, em caixas à prova de insetos ou em estufas. Nas experiências efetuadas em estufas ou em caixas, pode-se realizar o teste de uma maneira mais específica, usando-se uma espécie de afídeo de cada vez, para promover a infestação artificial dos clones ou variedades a serem estudadas. Nos ensaios efetuados em caixas ou em estufas, coloca-se um certo número de afídeos sôbre cada planta e depois de um certo tempo procede-se à contagem da população existente nas plantas de cada clone ou variedade.

Nos ensaios de campo tem-se sempre uma população mista de afídeos. Calcula-se também a resistência fazendo-se o levantamento da população de afídeos presentes nas plantas dos diferentes clones ou variedades. A tomada de amostra para determinação da população relativa de afídeos é feita da seguinte maneira (17) : retiram-se três fôlhas de um número variável de plantas de cada clone ou variedade: uma fôlha da base, uma da parte mediana e uma da parte superior da planta. $\bigcirc$ número total de plantas das quais se retiram as três fôlhas, varia naturalmente com o número de plantas por clone ou variedade. Para determinação da população de afídeos em um campo de uma só variedade, toma-se usualmente uma amostra de 100 plantas escolhidas ao acaso, ou seja 
um total de 300 fôlhas. É claro que, estudando-se muitos clones ou variedades, as amostras são naturalmente muito menores. Ao efetuar a contagem dos afídeos nas fôlhas, é útil separar os dados para as diferentes espécies. As fôlhas da batata têm geralmente 5 ou mais folíolos, tendo-se verificado que para determinação da população relativa de afídeos não é necessário contar os insetos em todos os folíolos. Contando-se os insetos presentes no folíolo apical e nos dois basais, obtêm-se figuras relativas, semelhantes àquelas que se obtêm examinando-se todos os folíolos.

No Estado do Maine, as espécies mais comuns em batata são três: Myzus persicae Sulz., Macrosiphum solanifolii Ashm e Aphis abbreviata Patch.

Os trabalhos a respeito da resistência aos afídeos ainda não estão bastante adiantados. Sabe-se, no entanto, que existe uma diferença em resistência entre as diferentes variedades. Solanum polyadenium parece ser altamente resistente a afídeos.

\section{Resistência a "psyllid-yellows"}

"Psyllid-yellows" é uma moléstia causada por substâncias tóxicas introduzidas na planta pelas picadas das ninfas do inseto causador, Paratrioza cockerelli (Sulc.). Os estudos quanto à resistência a esta moléstia têm sido feitos em estufas e no campo. Nos estudos efetuados em estufas, promove-se a infestação dos clones ou variedades com insetos criados artificialmente. Nos ensaios de campo não se faz pulverização alguma, para facilitar o desenvolvimento do inseto. As experiências feitas com relação a esta moléstia ainda estão na fase preliminar, não tendo sido obtido ainda nenhum resultado conclusivo quanto à resistência.

\section{ALGUMAS DAS NOVAS VARIEDADES QUE POSSUEM RESISTÊNCIA A MOLÉSTIAS OU INSETOS}

Em trabalhos recentes, Stevenson (20) e Stevenson e Akeley (24) dão uma lista das novas variedades que têm sido distribuidas aos lavradores. Esta inclue 5 variedades precoces: Earlaine, Mesaba, Nittany Cobbler, Red Warba e Warba e 9 variedades tardias: Kathadin, Chippewa, Houma, Earlaine 2, Golden, Pennigan, Pontiac, Sebago e Sequoia. Outras variedades foram introduzidas mais recentemente, como a Pawnee, Mohawk e Kasota.

\section{A variedade Kathadin :}

Esta variedade foi a primeira a ser distribuida aos lavradores depois da organização do "National Potato Breeding Program". É uma das 
que se tornou mais popular, tendo sido cultivada com sucesso ( ${ }^{*}$ ) em diversas regiões dos Estados Unidos, na Argentina, Uruguai e na Austrália (24). As vantagens apresentadas pela variedade Kathadin são as seguintes: é imune ao virus $\mathbf{A}$ por infeção com afídeos (16) ; é um tanto resistente ao enrolamento da fôlha e não mostra "net-necrosis". quando afetada (24) ; é bastante resistente à murcha bacteriana, causada por Phytomonas solanacearum (24). Aparentemente as qualidades de mesa da var. Kathadin não são tão boas como as de Green Mountain. Os tubérculos são muito bem conformados e têm olhos rasos.

\section{Chippewa :}

É também imune ao virus $\mathbf{A}$, quanto à transmissão por afídeos. É tão suscetível ao enrolamento da fôlha como Green Mountain, mas não apresenta "net-necrosis". É boa produtora e os tubérculos são muito bonitos, com os olhos rasos. As qualidades de mesa são inferiores à de Green Mountain. Chippewa tem uma tendência para mostrar um enrolamento das fôlhas de natureza fisiológica que pode ser confundido com o causado por virus, não havendo perigo de confusão no início do desenvolvimento das plantas, mas, sim, quando as plantas já são mais idosas.

\section{Golden :}

É a única das variedades novas que possue a polpa amarela. Não se tornou popular nos Estados Unidos, onde a preferência é para variedades de polpa branca. O seu cultivo já foi abandonado comercialmente. A produção e as qualidades dos tubérculos eram boas quando cultivados em condições favoráveis. O período de dormência era, porém, curto e isto constitue uma desvantagem para as condições do mercado americano. Conserva-se bem quando armazenada.

\section{Houma :}

Esta variedade produz satisfatòriamente e possue muito boas qualidades para mesa. É resistente ao virus $\mathbf{A}$ e não desenvolve "net-necrosis" quando afetada pelo enrolamento da fôlha. Apresenta também uma certa resistência à sêca.

(*) Em São Paulo esta variedade já foi experimentada, tendo dado resultados satisfatórios. O número de tubérculos produzidos por planta é pequeno, mas estes têm conformação e aparência muito bonitas. 


\section{Sebago :}

É uma variedade de muito boa produtividade. Apresenta resistência ao virus A. É suscetível ao enrolamento da fôlha, mas não desenvolve "net-necrosis". Apresenta alguma resistência ao crestamento fitóftora e à murcha bacteriana causada por Phytomonas solanacearum. É também resistente a "yellow dwarf". As suas qualidades de mesa não são tão boas como as de Green Mountain.

\section{Sequoia :}

É ótima produtora e possue boas qualidades de mesa, se bem que inferiores às de Green Mountain. Os tubérculos, são, às vêzes, demasiadamente grandes, apresentando então uma tendência para serem um tanto ásperos. É algo resistente ao virus $\mathbf{A}$, ao crestamento fitóftora e é altamente tolerante a "hopper-burn" e aos danos causados pela pulguinha.

\section{CONSIDERAÇÕES A RESPEITO DO MELHORAMENTO DA BATATA EM SÃO PAULO}

Pode-se dizer que, quase sem exceção, tôdas as moléstias aquí mencionadas e que constituem problemas importantes da cultura da batata nos Estados Unidos, são também de grande importância econômica em São Paulo. Constitue uma exceção a moléstia "ring-rot" causada por Phytomonas sepedonica, cuja presença em São Paulo ainda não foi constatada. Não seria, porém, de admirar se alguns dos casos de murcha bacteriana encontrados neste Estado fôssem devidos a êsse organismo.

Além dos problemas mencionados, temos algurs que apresentam grande importância sob as nossas condições e que não estão sendo estudados nos Estados Unidos. Tal é, por exemplo, o caso das galhas dos tubérculos causadas por Heterodera marioni.

A cultura da batata em São Paulo e em outros Estados do Brasil, é feita tôda ela com variedades introduzidas de outros países, seja mais recentemente ou em épocas passadas. É claro que mesmo as variedades que são aquí boas produtoras, não foram selecionadas para o conjunto de condições ecológicas locais.

Os trabalhos com a batata foram iniciados no Instituto Agronômico há já muitos anos. Desde 1929 até 1935 estiveram a cargo da Secção de Genética, passando posteriormente a ser atribuição da Seç̧ão de Rázes e Tubérculos.

Desde o início dêstes trabalhos, a atenção dos técnicos encarregados dêste serviço tem sido voltada para os problemas de variedades, 
zonas ecológicas favoráveis à planta e onde a disseminação das mc: léstias seja pequena, adubação, etc. $\mathrm{O}$ estudo das variedades que melhor se adaptem às nossas condições é um dos trabalhos que tem recebido mais atenção. É, todavia, fácil de se compreender, que se procurarmos boas variedades para as nossas condições, essa busca não deve ser feita ùnicamente dentro das variedades comerciais já existentes em outros países e que constituem material selecionado para outras condições. Trata-se, portanto, de um material já relativamente limitado, sob o ponto de vista genético. Cêrca de 150 diferentes variedades de batata já foram estudadas em São Paulo, pelas Secção de Genética, e de Raizes e Tubérculos dêste Instituto. Isto é um número elevado, mas quando se considera que nos projetos de criação de variedades se trabalha anualmente com muitos milhares de "seedlings", compreende-se que as possibilidades de se encontrarem variedades mais adaptadas para' as nossas condições são maiores neste último caso.

A criação de novas variedades de batata, especialmente adaptadas às nossas condições, oferece grandes perspectivas para São Paulo. Diversas tentativas para obtenção de novas variedades foram feitas na Secção de Genética do Instituto Agronômico. Em geral, não tem sido possível chegar-se a uma conclusão satisfatória nestes trabalhos, principal' mente por falta de um lugar adequado para a execução dos mesmos: Para que um projeto de tal nátureza fôsse levado avante, tornar-se-ia necessária a existência de uma estação experimental especializada, localizada em zona favorável a esta planta, como, por exemplo, Cascata; Campos do Jordão, Cunha, etc.

Durante a nossa visità à zona de batatas do Estado de Maine, nos Estados Unidos, tivemos ocasião de visitar demoradamente a Aroostook Farm, próxima à cidade de Presque Isle; estação experimental especializada para a batata. Nessa fazenda, trabalham em colaboração numerosos técnicos estaduais da Universidade do Maine e também técnicos federais do U.S. Departement of Agriculture. $\AA$ existência de umà estação experimental similar em São Paulo viriá fácilitar enormementé a experimentação com está plänta, e, portanto, beneficiar esta cultura.

Caso fôssem feitas novas tentativas para criação de variedades đé batata poderiam ser seguidas duas linhàs principais para obtenção dos "seedlings". "Uma seria efetuando os cruzamentos ou autofecun dação de variedades que tivessem sido escolhidas por êste ou aquêlé caraterístico, para obtenção das sementes verdadeiras que nos iriant fornecer os "seedlings". A outra possibilidade, talvez, mais fácil, seria aproveitar o grande esfôrço feito hoos Estados Unidos a êste respeitò 
e obter amostras dos "seedlings" já criados, antes que os mesmos tenham sido selecionados $\left({ }^{*}\right)$. Desta maneira obtém-se um material genético farto, pois é sabido que a seleção limita as possibilidades genéticas de um dado material.

\section{LITERATURA CITADA}

1. Allen, T. C. e G. H. Rieman. Occurrence of hopperburn resistance and susceptibility in the potato. Amer. Potato Jour. 16: 139-142. 1939.

2. Allen, T. C., G. H. Rieman, e J. S. Mc Farlane. Influence of planting date on potato leafhopper population and hopperburn development. Amer. Potato Jour. 17: 283-286. 1940.

3. Anonimous. Fruit and Vegetable Weekly Crop and Market Report. Dominion Department of Agriculture. Canada. is (9) : I-11. 1943.

4. Bonde, Reiner, F. J. Stevenson, C. F. Clark e Robert V. Akeley, Resistance of certain varieties and seedling progenies to ring-rot. Phytopath. 32: 813-819. 1942.

5. Clark, Charles F. The development of potato varieties in the United States. Proceedings of the Potato Association of America. 5-8. Dec. 1925.

6. Clarke, A. E., e P. M. Lombard. Relation of length of day to flower and seed production in potato varieties. Amer. Potato Jour. 16: 236-244. 1939.

7. Edmundson, W. C. Response of Several varieties of potatoes to different photo periods. Amer. Potato Jour. 18: 100-112. 1941.

8. Jones, Leon $\mathbf{K}$. and C. L. Vincent. The susceptibility of potatoes to the veinban. ding virus. Jour. Agr. Res. 55: 69-79. 1937.

9.Leach, J. G., P. Decker e Hannah Becker. Pathogenic races of Actinomyces scabies in relation to scab resistance. Phytopath. 29: 204-209, 1939.

10. Lunden, A. P. Averlighet sundersokslser i potet (Inheritance studies in the potato Solanum tuberosum L. ). Meld. Norg. Landbr. Horsb. 17: 1-156. 1937.

11. Raleigh, W. P. An abnormal graft reaction in potato resulting from a virus infection of a scion on a resistant stock. Phytopathology 26: 795. 1936.

12. Reddick, D. Scab immunity. Amer. Potato Jour. 16: 71-75. 1939.

13. Reddick, Donald e Welford Mills. Building up virulence in Phytophthora infestans. Amer. Potato Jour. 15: 29-34. 1938.

14. Reddick, Donald and W. R. Mills. Blight immune versus blight resistant potatoes. Amer. Potato Jour. 16: 220-224. 1939.

15. Schultz, E. S. ot al. Recent developments in potato breeding for resistance to virus diseases. Phytopath. 27: 190-197. 1937.

16. Schultz, E. S., C. F. Clark e F. J. Stevenson. Resistance of potato to viruses A and X, components of mild mosaic. Phytopathology 30: 944-951. 1940.

( *) Quando em visita ao dr. F. J. Stevenson em Beltsville no Estado de Maryland, conversamos com aquêle técnico a êste respeito. $O \mathrm{dr}$. Stevenson prontificou-se a nos remeter, anualmente, amostras de tubérculos de cêrca de 400 "seedlings" de variedades de polpa branca e amarela, antes que os mesmos tivessem sido selecionados. Além dêste material, o dr. Stevenson prontificou-se a remeter-nos amostras de cêrca de 15 novas variedades criadas naquele país. 
17. Simpson, G. W. Aphids and their relation to the field transmission of potato virus diseases in Northeastern Maine. Maine Agr. Exp. Sta. Bull. 403: 189-305. 1940.

18. Sleesman, J. P. e F. J. Stevenson. Breeding a potato resistant to the potato leaf-hopper. Amer. Potato Jour. 18: 280-298. 1941.

19. Stevenson, F. J. Late blight resistance in potato varieties as reflected in yields. Amer. Potato Jour. 16: 229-232. 1939.

20. Stevenson, F. J. Potato varieties recently distributed to growers in the United States. Amer. Potato Jour. 17: 217-235. 1940.

21. Stevenson, F. J. and C. F. Clark. Breeding e genetics in potato improvement. U.S.D.A., Yearbook 1937 : 405-444. 1937.

22. Stevenson, F. J. et al. Breeding for resistance to late blight in the potato. Phytopathology 27: 1.059-1.070. 1937.

23. Stevenson, F. J., E. S. Schultz, e C. F. Clark. Inheritance of immunity from virus X (latent mosaic) in the potato. Phytopathology 29: 362-365. 1939.

24. Stevenson, F. J. e R. V. Akeley. Newer potato varieties can be produced with less labor and expense than some of the old. Amer. Potato Jour. 19: 153-161. 1942.

25. Stevenson, F. J., Donald Folsom e T. P. Dykstra. Yirus leaf roll resistance in the potato. Amer. Potato Jour. 20: 1-10. 1943.

26. Stuart, William. Em The potato. J. B. Lippincott Company. 1928.

27. Werner, H. O. Effect on berry production of varied day length during the life of two Triumph potato strains. Amer. Potato Jour. 18: 174-178. 1941. 